Article

\title{
Using Molecular Networking for Microbial Secondary Metabolite Bioprospecting
}

\author{
Kevin Purves ${ }^{1}$, Lynsey Macintyre ${ }^{2}$, Debra Brennan ${ }^{1}$, Guðmundur Ó. Hreggviðsson ${ }^{3,4}$, \\ Eva Kuttner ${ }^{3}$, Margrét E. Ásgeirsdóttir ${ }^{3}$, Louise C. Young ${ }^{2}$, David H. Green ${ }^{1}$, \\ Ruangelie Edrada-Ebel ${ }^{2}$ and Katherine R. Duncan ${ }^{1, *}$ \\ Received: 23 September 2015; Accepted: 30 December 2015; Published: 8 January 2016 \\ Academic Editor: Peter Meikle \\ 1 Scottish Association for Marine Science, Scottish Marine Institute, Oban PA37 1QA, UK; \\ kep@pml.ac.uk (K.P); debra.brennan@sams.ac.uk (D.B); david.green@sams.ac.uk (D.H.G.) \\ 2 Strathclyde Institute of Pharmacy and Biomedical Sciences, University of Strathclyde, Glasgow G1 1XQ, UK; \\ lynsey.macintyre@strath.ac.uk (L.M.); louise.young@strath.ac.uk (L.C.Y.); \\ ruangelie.edra-ebel@strath.ac.uk (R.E.-E.) \\ 3 Matis, Vinlandsleið 12, Reykjavik 113, Iceland; gudmundo@matis.is (G.O.H.); eva.kuttner@matis.is (E.K.); \\ margreteva@matis.is (M.E.A) \\ 4 Faculty of Life and Environmental Sciences, University of Iceland, 101 Reykjavik, Iceland \\ * Correspondence: katherine.duncan@sams.ac.uk; Tel.: +44-1631-559-411
}

\begin{abstract}
The oceans represent an understudied resource for the isolation of bacteria with the potential to produce novel secondary metabolites. In particular, actinomyces are well known to produce chemically diverse metabolites with a wide range of biological activities. This study characterised spore-forming bacteria from both Scottish and Antarctic sediments to assess the influence of isolation location on secondary metabolite production. Due to the selective isolation method used, all 85 isolates belonged to the phyla Firmicutes and Actinobacteria, with the majority of isolates belonging to the genera Bacillus and Streptomyces. Based on morphology, thirty-eight isolates were chosen for chemical investigation. Molecular networking based on chemical profiles (HR-MS/MS) of fermentation extracts was used to compare complex metabolite extracts. The results revealed $40 \%$ and $42 \%$ of parent ions were produced by Antarctic and Scottish isolated bacteria, respectively, and only $8 \%$ of networked metabolites were shared between these locations, implying a high degree of biogeographic influence upon secondary metabolite production. The resulting molecular network contained over 3500 parent ions with a mass range of $m / z 149-2558$ illustrating the wealth of metabolites produced. Furthermore, seven fermentation extracts showed bioactivity against epithelial colon adenocarcinoma cells, demonstrating the potential for the discovery of novel bioactive compounds from these understudied locations.
\end{abstract}

Keywords: molecular networking; secondary metabolites; bioprospecting; bacteria; Antarctica

\section{Introduction}

Secondary metabolites have had a profound impact on human health, nutrition and society, since their initial discovery in the 1920s [1]. These natural products have been utilized for a number of applications such as antiparasitic [2], antimalarial [3,4], immunosuppressant [5,6], anticancer [7-9] and antibiotic $[10,11]$ applications. Recently, the rise of antimicrobial-resistant bacteria has provided motivation for novel bioactive compound discovery, as it has been recognised by the World Health Organization as a threat to human health $[12,13]$.

Through sequencing, unprecedented levels of marine microbial diversity have been revealed [14] across a range of habitats, including Arctic soils [14,15], permafrost soil in Greenland [16], the Canadian 
high Arctic [17], marine invertebrates [18-21] and the deep sea [14,15]. Bacterial bioprospecting within these understudied marine environments has yielded novel bioactive compounds [22-24], including abysomycin C, a polycyclic polyketide isolated from a marine Verrucosispora strain with activity against methicillin resistant Staphlycoccus aureus [25] and salinosporamide A, a proteasome inhibitor isolated from Salinispora tropica [26]. Of the total microbial bioactive metabolites identified $45 \%$ are produced by Actinomycetales, and within this, a single genus (Streptomyces) is responsible for $75 \%$ of these metabolites [27]. Members of the spore-forming genus Bacillus have also demonstrated versatile secondary metabolite production with diverse structural features and biological activities [28-30]. The lack of natural product discovery from Antarctica is likely as a result of the challenges associated with sampling from this region [31]. However, due to the ability of Bacilli and many actinomycetes to reside as spores, obtaining sediment samples from Antarctic depths could yield actinomycetes, as was found by the Challenger Deep Expedition in 2006, which cultivated thirty-eight actinomycetes from the Mariana Trench (10898 m) [32]. As a result, the isolation of novel bacteria from underexplored localities (i.e., Scotland and Antarctica) is a potential approach for uncovering novel bioactive compounds.

Bacteria have the ability to adapt to extreme parameters, including, temperature, salinity and $\mathrm{pH}$, which can result in ecologically-adapted populations residing in niche geographic habitats [14,32-36]. Horizontal gene transfer has been shown to be an important driver of bacterial diversification, whereby genes involved in natural product biosynthesis are swapped between taxa, resulting in great chemical diversity [37,38]. Over time, this adaptation can result in distinct phylogenetic taxa and the evolution of secondary metabolite biosynthetic genes in response to these ecosystem parameters. Therefore, understudied or extreme environments have the potential capacity to be a source of novel natural products $[25,39,40]$.

Molecular networking allows rapid comparison of mass spectrometry profiles from complex crude fermentation extracts, for effective chemical dereplication and novel metabolite discovery. Molecular networks utilize high-resolution mass spectrometry parent ion fragmentation data (MS/MS) [41]. These parent ions are connected based on the chemical architecture of the compound. Similar compounds have similar parent ion fragmentation patterns, which is computed as a cosine score from 1 (identical fragmentation spectra) to 0 (completely different parent ions) [41,42]. The parent ions (nodes) are therefore connected by edges (cosine score), which results in analogous or structurally similar compounds grouping together in molecular families [41,43]. This is an exceptionally efficient and sensitive method for comparison of metabolite profiles and complex high-resolution mass spectrometry data. Molecular networking has been demonstrated for rapid chemical dereplication of complex crude fermentation extracts [44] and has been combined with pattern-based genome mining to assess the pan-metabolome of 35 Salinispora strains with the discovery of the novel compound retemycin A [45] and used in conjunction with glycogenomics [46] and peptidogenomics [47]. The comparative approach of chemical profiles has allowed changes in secondary metabolites in response to intraspecific interactions to be assessed for the cyanobacteria Microcystis [48] and it has been used to profile marine cyanobacteria metabolomes [49]. Molecular networking has also been combined with two and three-dimensional visualization of metabolites using real-time and imaging mass spectrometry [50] and stable isotope labelling for biosynthetic pathway characterization in fungi [51].

The current study establishes a taxonomically selective culture collection to investigate the potential of bacteria from both Scottish and Antarctic sediments to produce bioactive secondary metabolites. Culture-dependent approaches, utilising a variety of media and pre-treatments were employed to select for spore-forming bacteria (actinomyces and Bacillus), followed by taxonomic identification and phylogenetic analysis. Their secondary metabolites were investigated using tandem high-resolution mass spectrometry of fermentation extracts, followed by metabolite dereplication using molecular networking and bioactivity testing against epithelial colon adenocarcinoma cells. 


\section{Results and Discussion}

\subsection{Phylogenetic and Taxonomic Identification of Antarctic and Scottish Bacterial Isolates}

Scottish sediments, sampled from three locations on the East coast and the Outer and Inner Hebrides, were used to isolate sixty-seven bacterial strains (Figure S1) following a selective cultivation approach encompassing five different media and two pre-treatments (Dilute Heat, DH; Dry Stamp, DS). The St. Andrews sediment yielded the highest number of isolates with $70.2 \%$ of all the Scottish bacteria isolated from this location using the DS pretreatment, followed by $7.5 \%$ using the DH pretreatment. The sediment taken from Calgary Bay yielded the second-highest number of isolates (13 bacteria, $19.4 \%)$. The isolation media generating the highest number of isolates was Starch Casein Nitrate (SC) $(38.8 \%$ of the total isolates) followed by Raffinose-Histidine (RH) $(17.9 \%)$. The combination of SC media, DS pre-treatment and St. Andrews sediment provided the highest number of bacterial isolates $(26.9 \%)$. This supports previous studies that showed the highest number of actinomycetes were isolated from Canadian sediment using RH and SC media [23,52].

Antarctic sediments from four locations around the outer rim of the Weddell Sea were plated on five selective isolation media and yielded eighteen bacterial strains (Figure S2). The highest number of isolates was obtained from the Bransfield Strait (50.0\%) of which seven strains (38.9\%) were isolated using RH media. Wegener Canyon sediment that was plated on AI media and Bransfield Straight sediment that was plated on SC media yielded the highest number of isolates ( $22.2 \%$ each). Chitin Low Nutrient (M4) and Phosphate-Nitrate (M3) media yielded no bacterial isolates from any of the Antarctic samples. This is in contrast with two studies that cultured actinomycetes from marine sediments of Newfoundland and New Brunswick (Canada), as these media were shown to yield multiple bacterial isolates (M3: 59 and 113 isolates; M4: 41 and 19 isolates, respectively) [23,53]. Murray and Grzymski [54] found Actinobacteria were one of the main bacterial phylogenetic groups isolated from marine samples from Antarctica, which is likely due to the resilience of spore-forming bacteria to desiccation and sub-zero temperatures over extended time periods [55-57]. In this study, the prolonged time since the Antarctic (sampled 2002 and 2005) and Scottish (sampled 1990) sediments were collected may have impacted the number of bacteria isolated. To circumvent this issue, this study also investigated more recently sampled Scottish sediment (St. Andrews sediments, sampled in 2013) [58]. The selective isolation methods employed have been shown to yield high actinomycete diversity [58-61]. The lower number of Antarctic isolates may be a result of applying methods less amenable to bacterial isolation from extreme habitats that encompass abyssal depths, pressures and temperatures. However, Weyland et al. investigated actinomycete abundance of marine sediments from various locations and were unable to isolate any actinomycetes from Antarctic sediment [62], indicating that the methodology used herein may have contributed to the successful isolation.

Furthermore, 16S rRNA gene sequencing of the 85 isolates revealed fine scale phylogenetic diversity (Figure 1) encompassing eight genera, including Bacillus (62.4\%), Streptomyces (15.5\%), Micromonospora (4.7\%), Paenibacillus (4.7\%), Kocuria (3.5\%), Verrucosispora (2.4\%), Staphylococcus $(1.2 \%)$, Micrococcus (1.2\%) and four unidentified bacteria (4.7\%) (Table S1). A total of thirty-eight isolates were chosen for chemical investigation based on morphology (Figure 1). These isolates were subsequently sequenced and belonged to the genera Bacilllus (11 Scottish, 10 Antarctic isolates), Streptomyces (5 Scottish, 2 Antarctic), Kocuria (3 Antarctic), Micromonosprora (2 Scottish), Micrococcus (1 Scottish) and four unidentified isolates from Antarctica (Table S1).

As a result of the targeted methodology to isolate spore-forming bacteria (Bacillus and actinomycetes) from Antarctic and Scottish sediment [27,58], the dominant genera cultured were Bacillus (62\%) and Streptomyces (15\%). A study of deep sea, anoxic brine lake sediments in the Eastern Mediterranean revealed Bacillus-like organisms to be the dominant cultured bacteria [63]. Similar to this study, a phylogenetic identification of marine bacteria isolated from deep-sea sediments from the South Atlantic Ocean yielded Bacillus as the most frequently identified genus [64]. In this study, strains from the rare actinomycete genus Kocuria were only isolated from the Antarctic sediments. Previously, 
Kocuria spp., isolated from Florida (USA), have been shown to produce antibacterial compounds (kocurin) effective against methicillin resistant $S$. aureus [65].

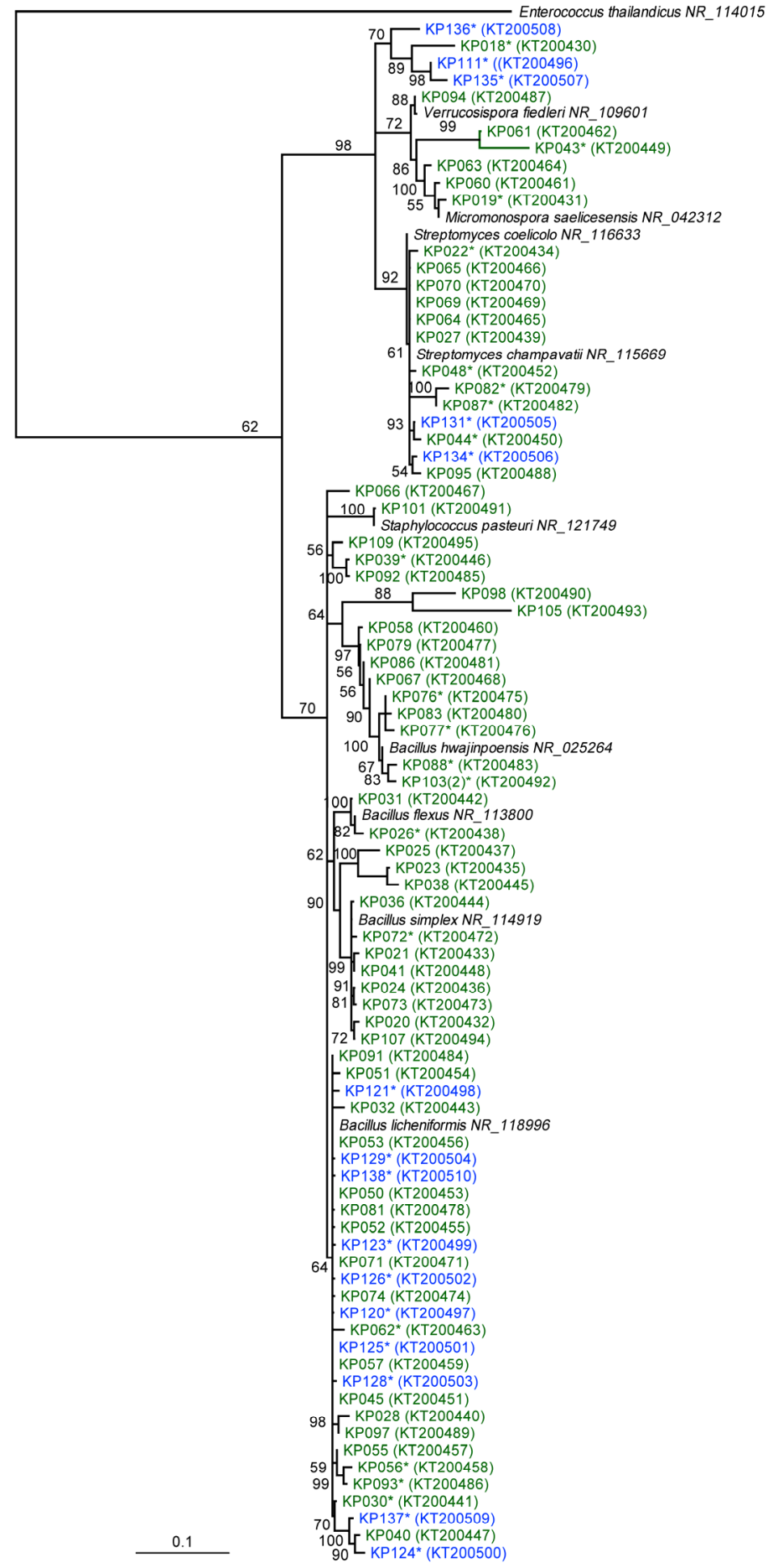

Figure 1. Neighbour-joining tree based on almost complete $16 \mathrm{~S}$ rRNA gene sequences, showing the phylogenetic relationships between 81 Scottish and Antarctic bacterial isolates (KP011, KP122, KP130 and KP133 were excluded from the tree) with NCBI accession numbers in brackets. Bootstrap support $>50 \%$ based on a neighbour-joining analysis of 1000 resampled datasets is shown. Scale bar, 0.1 substitutions per nucleotide position. * strains subjected to metabolite comparison through molecular networking. Branches are colour-coded according to their isolation location (Scotland, Green; Antarctica, Blue) for each bacterial isolate. 


\subsection{Comparative Metabolomics}

Molecular networking of metabolite mass spectrometry profiles from 38 bacteria was visualized by bacterial isolation location (Scotland and Antarctica) and resulted in a molecular network containing 3558 parent ions (nodes) (Figure 2). The node size indicates the number of strains producing the parent ion and as expected, media components have larger node sizes due to their ubiquitous presence in fermentation extracts (Figure 2). Parent ions within the molecular network only matched three known standards (within the molecular networking databases), the siderophore desferrioxamine $\mathrm{E}$ ( $m / z$ 601.358) produced by one Antarctic Streptomyces strain (KP131), surfactin C14 (m/z 1022.73) and surfactin C15 ( $m / z$ 1036.74) (both shown as non-charged ions in the molecular network) produced by four Bacillus strains, three from Scotland (KP056, KP088 and KP129) and one from Antarctica (KP129) (data not shown). For all three known compounds, example MS/MS parent ion fragmentation data from this study and the molecular networking standards were compared (Figure 3).

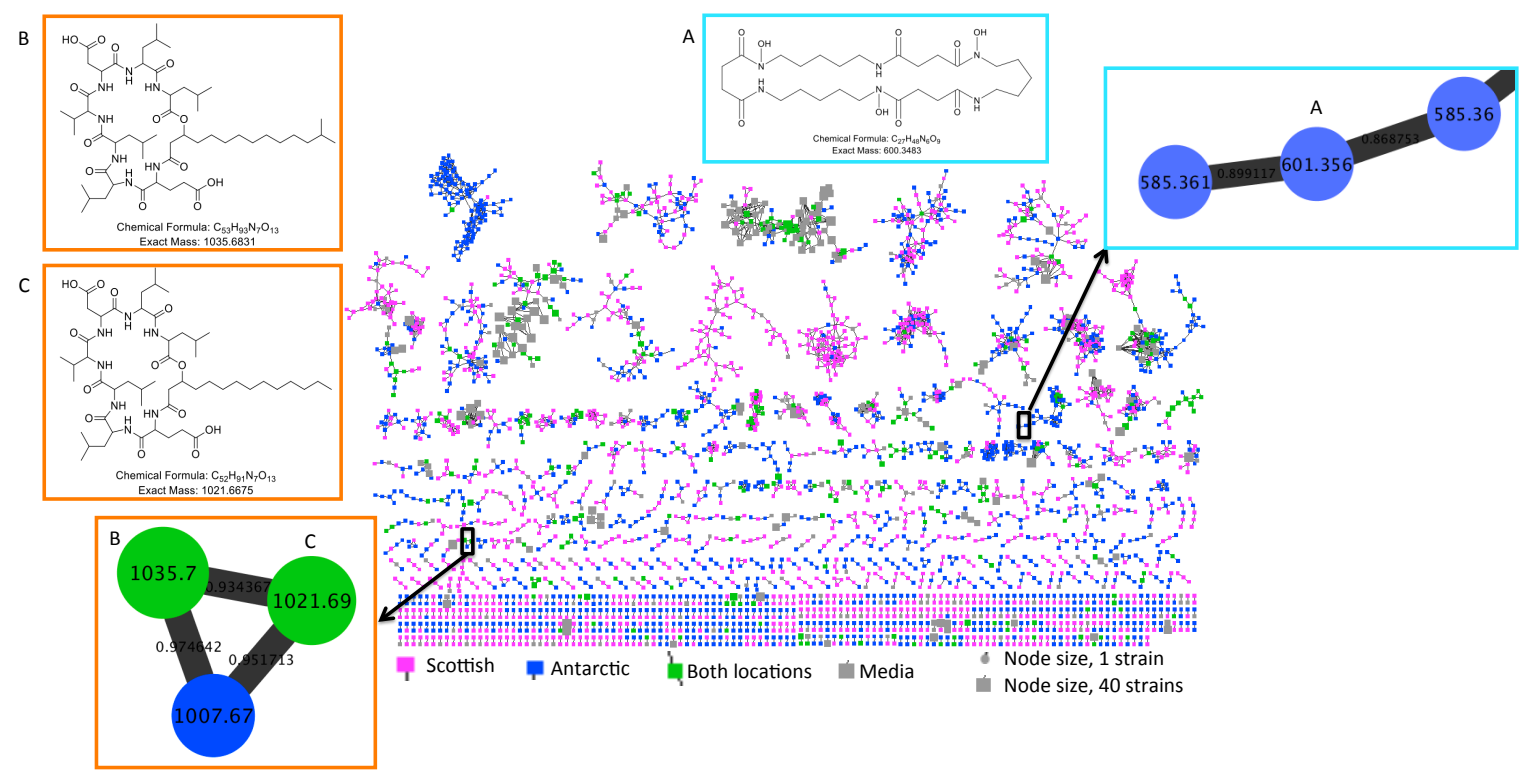

Figure 2. Molecular network of 3558 parent ions produced by 38 bacterial strains. Nodes colours are based on bacterial isolation location, where nodes representing parent ions are produced by strains isolated from Antarctic sediment, Scottish sediment or both. Grey nodes represent media components and the node size reflects the number of strains that produced each parent ion. Nodes highlighted in coloured boxes represent parent ions that are identified as the previously discovered metabolites (A) desferrioxamine E (B) surfactin C14 and (C) surfactin C15.

The number of parent ions produced (i.e., not media components) varied from strain specific production (79.4\% parent ions in the molecular network) to production of parent ions by 10 strains. No parent ion was produced by all strains. This strain specificity yields great potential for the discovery of bioactive metabolites, whereby each strain contributes a high percentage of unique chemistry. The molecular network revealed that 2923 (82\%) of parent ions were unique to either the Antarctic or Scottish isolates. A total of 1422 metabolites (39.9\% of the total ions in the molecular network) were Antarctic specific secondary metabolites, whilst 1501 (42.1\%) of metabolites were Scottish-specific. Remarkably, only 278 ions (7.8\%) were produced by isolates from both locations (Figure 4). This contradicts previous observations of species specific metabolite production from the genus Salinispora [66]. 

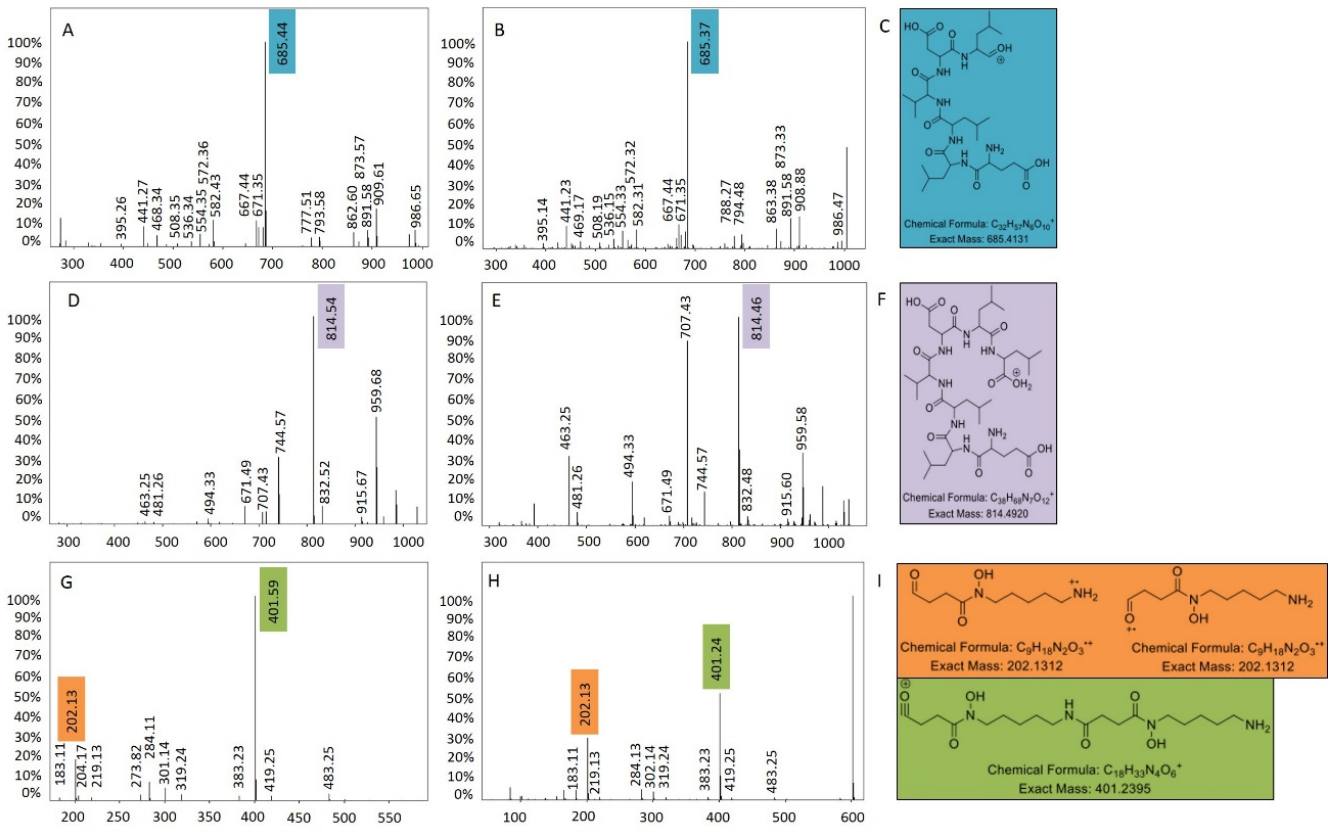

$m / 2$

$m / 2$

Figure 3. Surfactin C14 (A) MS/MS parent ion fragmentation for this study (B) MS/MS parent ion fragmentation for the molecular networking standard (C) major fragment ion; surfactin C15; (D) MS/MS parent ion fragmentation for this study; (E) MS/MS parent ion fragmentation for the molecular networking standard; (F) major fragment ion and desferrioxamine E (G) MS/MS parent ion fragmentation for this study; (H) MS/MS parent ion fragmentation for the molecular networking standard; (I) major fragment ions.

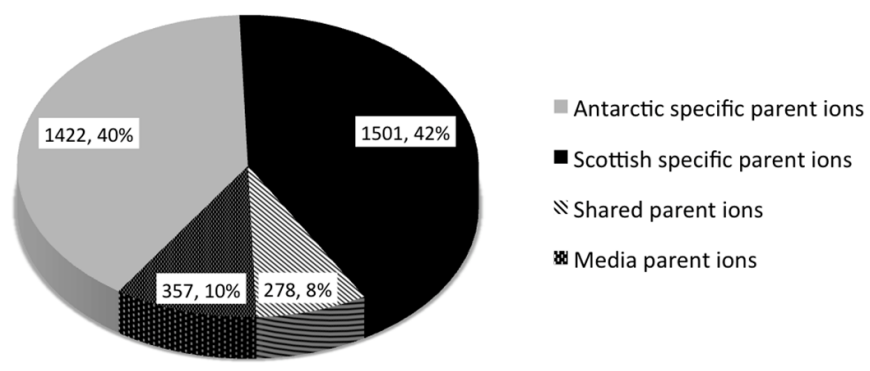

Figure 4. Relative proportions of location-specific parent ions identified by molecular network analysis (Figure 2).

To address this further, ten Bacillus lichenformis strains (five isolated from both Scotland and Antarctica) sharing $>98 \% 16 \mathrm{~S}$ rRNA gene sequence identities were selected for molecular networking, resulting in 315 parent ions (Figure 5). In total $43.8 \%$ of the B. lichenformis produced parent ions were specific to either Scotland (16.2\%) or Antarctica (27.6\%), which is a lower number than when all taxa were compared. In addition, the number of ions shared between these locations was $29.5 \%$, again, higher than the $8 \%$ shared when comparing all bacterial taxa. In order to compare additional species, a higher number of highly related species or strains ( $>98 \% 16 \mathrm{~S}$ rRNA gene sequence similarity) would be required. It is, however, surprising that although such high sequence similarity across all ten strains exists, almost half of all parent ions in the molecular network are produced by strains from either Scotland or Antarctica, and not ubiquitously produced. This suggests that ecological differentiation has had a marked impact on the types of secondary metabolites that are produced by these taxonomically closely related strains. 
Jensen et al. (2006) [67] investigated the biogeography of the genus Salinispora and concluded that due to the co-occurrence of three distinct clades, ecological differentiation is more important to speciation than biogeography. However, evidence of location specificity has been revealed when it was discovered that similar soil types contain related secondary metabolite genes [68]. It is important to note, however, that location may not be the only cause for the strain specific metabolomes in this study, due to the very extreme ecological differentiation between Antarctic and Scottish sediment. Strain specific metabolite production has been demonstrated recently by Duncan et al., (2015) when 35 strains of three species of the marine actinomycete genus Salinispora were examined [45]. The data presented herein provides further evidence that strain specific metabolite production might be a wider occurrence across multiple bacterial taxa.
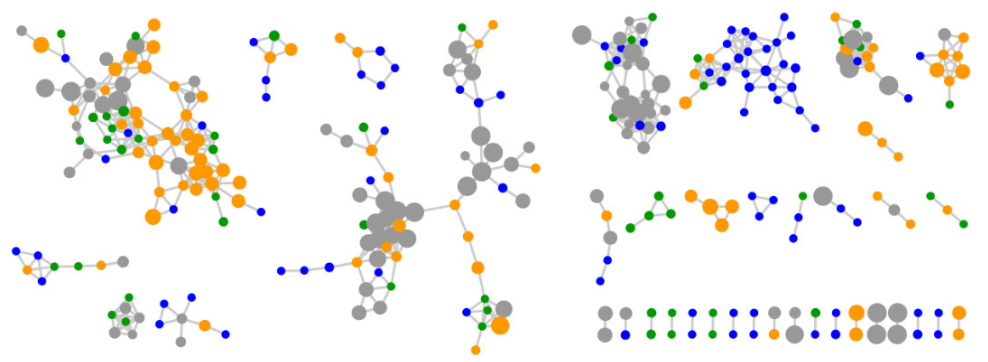

Figure 5. Molecular network with 315 parent ions produced by ten Bacullus licheniformis strains. Nodes representing ions produced by strains isolated from Scotland (KP30, KP30, KP56, KP62, KP93) and Antarctica (KP120, KP121, KP126, KP126, KP128) are green and blue, respectively. Nodes representing parent ions produced by strains isolated from both Scotland and Antarctica are orange and media components are grey. The node size reflects the number of strains that produce each parent ion from the smallest node (strain specific) to the largest node (10 strains).

Rarefaction curves were computed using the MS/MS spectra, which were used to generate the molecular network (Figure S3). This reflects the diversity of the fragmentation spectra (and thus the parent ions within the dataset). The curve does not reach an asymptote, suggesting that significant metabolite diversity would be uncovered by investigating more strains. The molecular network by parent ion mass (Figure S4) indicates that $71.7 \%$ of the nodes represent small molecules, with masses between $\mathrm{m} / \mathrm{z} 149$ and 300. As expected the percentages decrease with increasing parent ion mass, with $14.4 \%$ of the networked ions between $\mathrm{m} / \mathrm{z} 301$ and $500,9.8 \%$ between $\mathrm{m} / \mathrm{z} 501$ and 1000 and the largest parent ion masses $(m / z$ 1001-2558) representing 3.9\% of the networked ions. The molecular network exceeds 3500 individual nodes with mass ranges of $m / z$ 149-2558. Previously, a network of 21 Moorea, Lyngbya and Schizothrix strains revealed 1948 nodes (ranging between $\mathrm{m} / \mathrm{z} 300$ and 2000) [44]. Additionally, a molecular network of 35 Salinispora strains resulted in 1137 parent ions; however, mass values less than $m / z 300$ were experimentally excluded [45]. The higher node counts of this study are likely a result of no exclusion of ions below $\mathrm{m} / \mathrm{z} 300$.

The molecular network (Figure S5) of the 38 strains by taxonomic identification (closest match within the NCBI BLASTx database, Table S1) revealed that the 21 Bacillus strains produced the highest number of parent ions (1349 ions, 39.7\% of the network), followed by seven Streptomyces strains (477 ions, 14.1\%), three Kocuria strains (215 ions, 6.3\%) and two Micromonospora strains (156 ions, $4.6 \%$ ). To take into account the varying number of strains of each genus, the average number of parent ions produced per strain was calculated for each genus and found to be 64.2, 68.1, 71.7 and 78.0 for Bacillus, Streptomyces, Kocuria and Micromonospora respectively. The four taxonomically unidentified bacteria (KP011, KP122, KP130 and KP133) that were grouped with the single Micrococcus isolate (KP018) resulted in 431 ions, making up $12.7 \%$ of the total parent ions of the molecular network. Only 395 parent ions $(18.8 \%)$ crossed taxonomic boundaries and were produced by strains of more than two genera. 
A heat map based on mass spectrometry profiles and molecular weight revealed three isolates with distinct patterns, KP130 (a taxonomically unidentified bacteria isolated from Maud Rise, Antarctica), KP044 (a Streptomyces strain isolated from St. Andrews sediment) and KP121 (a Bacillus strain from Bransfield Strait, Antarctica) (Figure S6). These three strains can be seen as principle component analysis (PCA) outliers (Figure S7), and were also clearly identified in the molecular network, demonstrating the complementary nature of metabolomic tools for secondary metabolite discovery, such as PCA, database searches (Marinlit and Antibase) and molecular networking (Figure S8, Table S2). The metabolites responsible for these unique heat map profiles were identified using PCA and found to be a series of polymers $m / z$ 363-1911 with spacing of 86 Da (KP130); a series of the piscicides antimycins [69] known to be produced by Streptomyces spp. and which corresponded to ion $m / z$ observed by Viegelmann et al., (KP044) [70] and a series of unidentified small molecules below $\mathrm{m} / \mathrm{z} 350$ (KP121). The MS/MS fragmentation data for the antimycins from this study were compared with the data of Viegelmann et al. (Figure 6) [70]. The parent ion $\mathrm{m} / \mathrm{z} 521.24854$ showed fragmentation of the dilactone ring that generates a characteristic fragment ion at $m / z 265.081[\mathrm{M}+\mathrm{H}]^{+}$and the parent ion $m / z 493.21734$ showed no characteristic fragment ion of $m / z 265.081$ as also found by Viegelmann et al.; however, an ion fragment of $m / z 237.08704$ was detected which may be the characteristic fragment ion minus a carbonyl group (Figure 6). However, many ions within the crude extracts do not match standards within the molecular networking database in addition to not having matches when comparing the MS data with the natural products databases Marinlit and Antibase during dereplication (data not shown). This allows ions to be prioritized for future chemical investigations and suggests that there is high potential for novel compound discovery from these fermentation extracts. In the future, combining whole genome sequencing of these strains will help reveal the biosynthetic gene clusters responsible for these molecular families using bioinformatic approaches such as peptidogenomics [47] and glycogenomics [46]. This comparison technique, has been used to discover several novel bioactive compounds including anticancer compound retimycin A [45], antifungal compound thanamycin [41] the vitroprocins produced by marine Vibrio sp. with antibiotic activity [71] and malyngamide $C$ with a combination of antifungal and cytotoxic properties [49].

a)

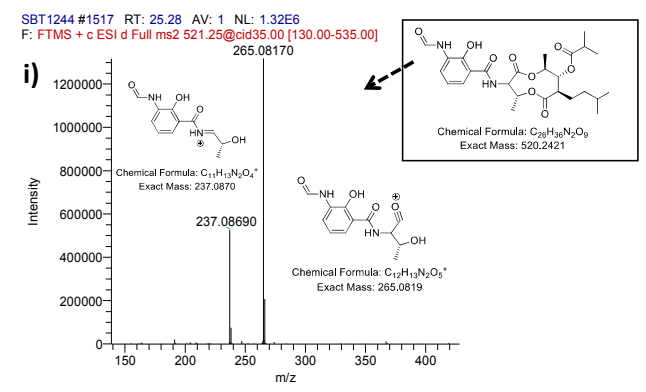

b)

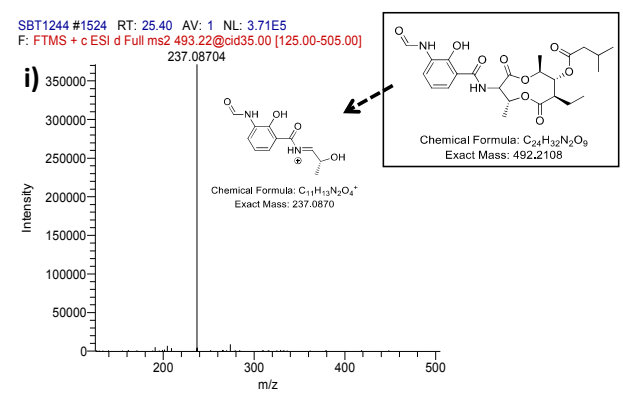

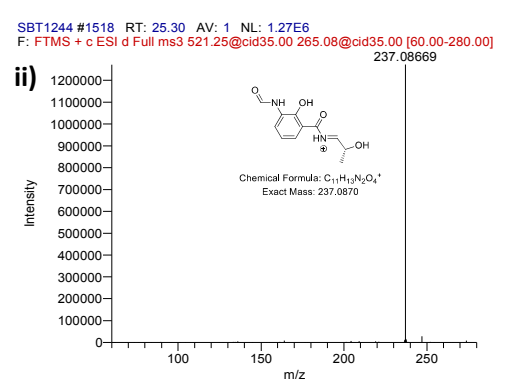

SBT1244 \#1525 RT: 25.42 AV: 1 NL: 6.30E4
F: FTMS + c ESI d Full ms $4393.22 @ 0$ cid $35.00237 .09 @$ @cid35.00 $155.00-250.00]$

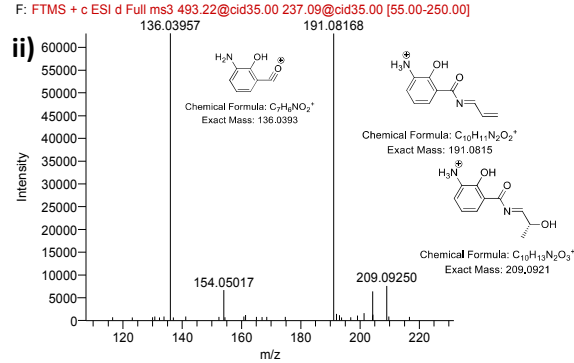

Figure 6. Fragmentation of parent ions that were tentatively assigned as antimycins showing fragmentation of (a) parent ion m/z m/z 521.24854 (Antimycin A3 or A7, $\mathrm{C}_{26} \mathrm{H}_{36} \mathrm{~N}_{2} \mathrm{O}_{9}$ ) and (b) parent ion $m / z 493.21734$ (Antimycin $\mathrm{A} 5, \mathrm{C}_{24} \mathrm{H}_{32} \mathrm{~N}_{2} \mathrm{O}_{9}$ ). $\mathrm{MS}^{2}$ spectra (i) and $\mathrm{MS}^{3}$ (ii) are annotated to illustrate the predicted fragmentation patterns of parent antimycins. 


\subsection{Bioactivity Testing}

A total of two blanks containing only ISP-2 media and organic extracts of all 38 strains selected for molecular networking were tested for cytotoxicity against two cell lines derived from different human tissue, i.e., epithelial colon adenocarcinoma cells (Caco-2) and human fibroblasts originating from foreskin (HS27) with the additional testing of 29 extracts (and two media blanks) against human epithelial prostate cells (PNT2) (Table S3). There was no effect on the viability of "normal" human cell lines, PNT2 and HS27, at the concentrations tested (30 $\mu \mathrm{g} / \mathrm{mL}$ and $100 \mu \mathrm{g} / \mathrm{mL})$. While seven fermentation extracts were bioactive against colon adenocarcinoma cells at the concentration tested (50 $\mathrm{gg} / \mathrm{mL}$ ) (Table S3). These seven metabolite extracts were then further tested at several concentrations $(10 \mu \mathrm{g} / \mathrm{mL}, 5 \mu \mathrm{g} / \mathrm{mL}, 1 \mu \mathrm{g} / \mathrm{mL}$ and $0.5 \mu \mathrm{g} / \mathrm{mL})$. IC 50 values were calculated that lowered cancer cell (Caco-2) viability to below 50\% (Table 1). Five of the seven Streptomyces strains tested (KP022, KP044, KP082, KP087 and KP131) showed inhibition of cell viability values between $63 \%-75 \%$ at the highest concentration tested $(50 \mu \mathrm{g} / \mathrm{mL})$. Additionally, two Bacillus strains (KP039 and KP077) isolated from Scotland showed cell viability inhibition of $47 \%$ and $75 \%$ respectively when tested at the highest concentration $(50 \mu \mathrm{g} / \mathrm{mL})$. All metabolite extracts influenced cell viability in a concentration-dependent manner. Direct observation revealed morphological changes, i.e., cell shrinkage and formation of apoptotic bodies (Figure 7). Both media blanks were tested and found to be inactive in the Caco-2 assay (Figure 7).

Table 1. $\mathrm{IC}_{50}$ values of seven metabolite extracts on Caco- 2 cells. The values given reduce viability to $50 \%$ after $48 \mathrm{~h}$ of exposure.

\begin{tabular}{cc}
\hline Sample & IC $_{\mathbf{5 0}}(\mu \mathrm{g} / \mathrm{mL})$ \\
\hline KP022 & 6.2 \\
KP039 & 55.5 \\
KP044 & 0.1 \\
KP077 & 1.6 \\
KP082 & 30.0 \\
KP087 & 6.1 \\
KP131 & 31.4 \\
\hline
\end{tabular}

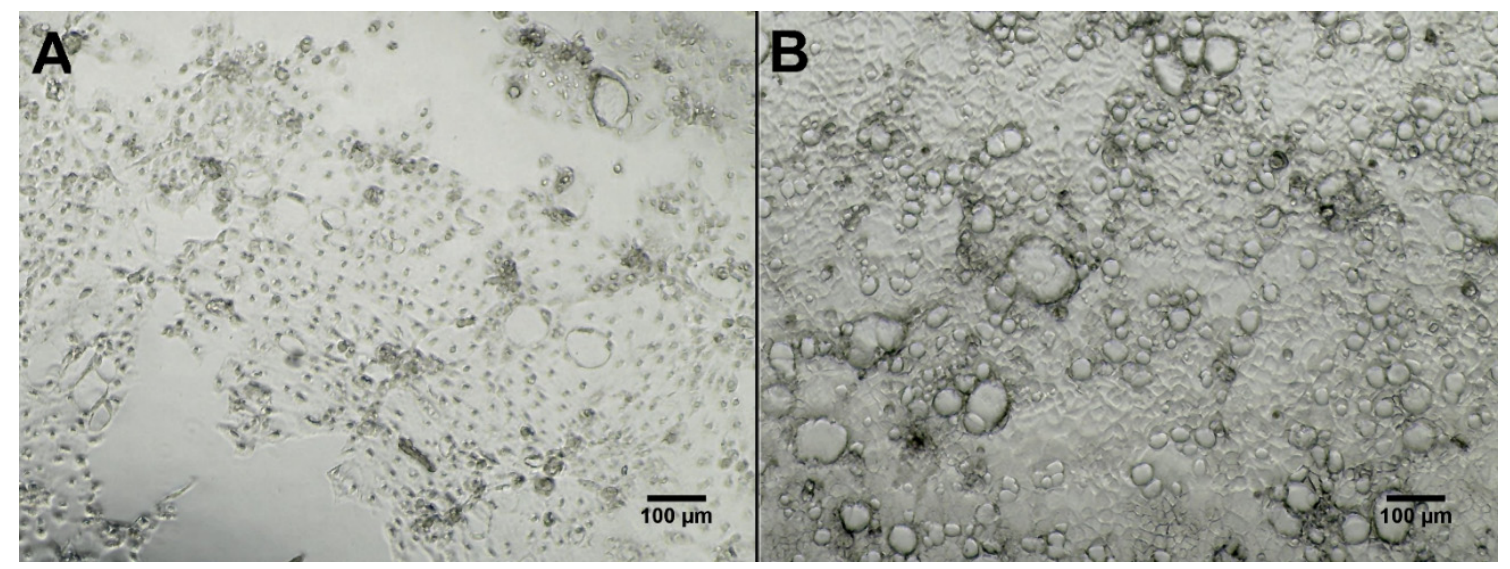

Figure 7. Micrographs (taken with EVOS XL Core Imaging system, $100 \times$ magnification in phase contrast) of Caco-2 cells seeded in 96 microplate wells after $48 \mathrm{~h}$ of exposure to metabolite extract of strain KP087 (A) at $10 \mu \mathrm{g} / \mathrm{mL}$ (viability test showed 37\% viability for this well) and medium blank (B) at $10 \mu \mathrm{g} / \mathrm{mL}$ (viability test showed 100\% viability for this well). Formation of apoptotic bodies can be seen in (A) as small black dots, as well as areas free of cells in the lower part of the picture as cells could no longer attach to plate. Cells exposed to medium blank (B) show full confluence where single cells cannot be distinguished. 
Metabolites produced by Streptomyces and Bacillus strains have previously demonstrated anticancer bioactivities [46,72-75]. Our results suggest potential anticancer activity of the extracts (Table 1), as "normal" cell lines were not affected. While cultured immortalized cell lines are no substitute for in vivo toxicity studies, they can be used for screening studies as a control. Further analysis is needed to identify the causes for the cytotoxicity to cancer cells and to isolate compounds responsible for the observed bioactivity.

\section{Experimental Section}

\subsection{Sample Collection and Processing}

In total, four sediment samples were collected during research cruises occurring in March 2002 and February 2005 around the outer rim of the Weddell Sea, Antarctica. The sediment samples were collected by box-core from a depth range between $1166 \mathrm{~m}$ and $4652 \mathrm{~m}$ [76,77]. Sediment cores were collected from the Bransfield Strait $\left(62^{\circ} 19.95 \mathrm{~S} 57^{\circ} 54.00 \mathrm{~W}\right)$, Wegener Canyon ( $\left.70^{\circ} 31.49 \mathrm{~S} 14^{\circ} 34.95 \mathrm{~W}\right)$, the Maud Rise $\left(67^{\circ} 30.99 S 0^{\circ} 0.16 \mathrm{E}\right)$ and the Weddell Sea $\left(62^{\circ} 57.68 \mathrm{~S} 27^{\circ} 53.51 \mathrm{~W}\right)$. These samples were stored in a temperature-controlled room $\left(4{ }^{\circ} \mathrm{C}\right)$, located at the Scottish Association for Marine Science. Sediment samples for bacterial isolation were removed from the collected cores aseptically using a sterile spatula and sterile $50 \mathrm{~mL}$ centrifuge tube and processed immediately. Scottish samples were taken from an intertidal zone of: St. Andrews, on the East Coast of Scotland (in 2013); the Monach Isles in the Outer Hebrides (in 1990); and Calgary Bay on Mull on the West Coast of Scotland (in 1990).

\subsection{Cultivable Bacterial Diversity}

A combination of sediment pre-treatments, selective isolation media and plating techniques were used to target spore forming actinomycetes and Bacillus genera. A dry-stamp (DS) pre-treatment was employed [58], which involved initially drying the sediment samples in a Muffle furnace $\left(60{ }^{\circ} \mathrm{C} ; 1.5 \mathrm{~h}\right)$. The dried samples were subsequent stamped onto the surface of agar plates (containing selective media) using sterile foam tops (approx. $3 \mathrm{~cm}$ diameter), the stamping occurred around the media surface to create a serial dilution effect. A dilute-heat $(\mathrm{DH})$ pre-treatment was also utilised, involving the dilution of $1 \mathrm{~mL}$ of wet sediment with $10 \mathrm{~mL}$ of sterile seawater, and then heating the sediment mixture $\left(55^{\circ} \mathrm{C} ; 6: 00 \mathrm{~min}\right)$ [58]. A $50-70 \mu \mathrm{L}$ aliquot of the resulting suspension was inoculated onto the agar plates. Each pre-treatment was inoculated onto five isolation media: AI Agar [59], SC Agar [60], RH Agar [60], M4 Agar [61] and M3 Agar [60]. All media were prepared with $18 \mathrm{~g} \cdot \mathrm{L}^{-1}$ Instant Ocean ${ }^{\circledR}$ (IO; Aquarium Systems, Sarrebourg, France) and sterilised by autoclaving. In total, five replicates of the DS pre-treatment and media combinations (AI, SC, RH, M4, M3) were plated for the Scottish isolates from all three sample locations, with five additional replicates for the $\mathrm{DH}$ pre-treatment and media combinations being plated from the St. Andrews location (resulting in 100 plates). Additionally, five replicates of DS pre-treatment and media combinations were plated for the Antarctic sediment samples (resulting in 125 plates). In total, 225 selective bacterial isolation plates were used. Plates were monitored over one month for the emergence of colonies exhibiting morphology typical of filamentous actinomycetes (includes a leathery substrate mycelia and the formation of aerial mycelia and spores). Colonies found to exhibit the desired morphologies were chosen for purification and initially subcultured onto fresh agar plates of the same media type from which they were isolated. Isolates were then phased onto International Streptomyces Project Medium 3 (ISP-3) [78]. Cultures were archived in $50 \%$ glycerol and stored $\left(-80^{\circ} \mathrm{C}\right)$.

\subsection{Bacterial Fermentation and Metabolite Extraction}

Cultures from agar plates were used to inoculate $7 \mathrm{~mL}$ of International Streptomyces Project Medium 2 (ISP-2) broth [78], supplemented with $18 \mathrm{~g} \cdot \mathrm{L}^{-1} \mathrm{IO}$, in culture tubes $(150 \times 15 \mathrm{~mm})$. The seed cultures were grown over a one-week period $\left(25^{\circ} \mathrm{C}\right.$; shaking at $\left.150 \mathrm{rpm}\right)$. Fermentations ( $250 \mathrm{~mL}$; ISP-2 medium $/ 18 \mathrm{~g} \cdot \mathrm{L}^{-1} \mathrm{IO} ; 1000 \mathrm{~mL}$ Erlenmeyer flask), which included activated Diaion ${ }^{\circledR}$ 
HP-20 resin, were inoculated with the seed culture and incubated under identical conditions for one week. The cells and resin were collected by centrifugation $(5000 \times \mathrm{g}, 10: 00 \mathrm{~min})$ in $50 \mathrm{~mL}$ Falcon tubes, where the supernatant was removed and the cells/resin combined in one Falcon tube, centrifuged and the supernatant removed. The cell/resin pellets were frozen $\left(-80^{\circ} \mathrm{C}\right.$; overnight), lyophilised and twice extracted (subsequently) with $20 \mathrm{~mL}$ of ethyl acetate (EtAOc) (Fisher Scientific, Leicester, UK) by agitation at $150 \mathrm{rpm}$ for $1 \mathrm{~h}$. Extracts were dried under nitrogen and the extract weights recorded.

\subsection{Molecular Networking}

High-resolution tandem mass spectrometry (HR-MS/MS) data for the 38 Antarctic and Scottish isolates was generated at the Strathclyde Institute of Pharmacy and Biomedical Science. Samples and ISP2 medium control samples were prepared at concentration of $1 \mathrm{mg} / \mathrm{mL}$ in 80:20 MeOH: DCM as previously described [79]. Data dependent MS/MS experiments were carried out using a Finnigan LTQ Orbitrap coupled to a Surveyor Plus HPLC pump and autosampler (Thermo Fisher, Bremen, Germany) in positive ionization modes using a MS range of $m / z 100-2000$, a MS2 range of $m / z$ 200-1500, a MSn range of $m / z$ 0-1000 and 30,000 resolution as previously described [79]. LC-MS data was acquired using Xcalibur version 2.2.

HR-MS/MS raw data files were converted from .RAW to .mzXML file format using the Trans-Proteomic pipeline (Institute for Systems Biology, Seattle) [80], and clustered with MS-Cluster using Global Natural Products Social (GNPS) Molecular Networking [42,81-83]. A molecular network was created using the online workflow at GNPS. The data was filtered by removing all MS/MS peaks within $\pm 17 \mathrm{Da}$ of the precursor $\mathrm{m} / \mathrm{z}$. MS/MS spectra were window filtered by choosing only the top 6 peaks in the \pm 50 Da window throughout the spectrum. The data were then clustered with MS-Cluster with a parent mass tolerance of 2.0 Da and a MS/MS fragment ion tolerance of 0.5 Da to create consensus spectra. Further, consensus spectra that contained less than 1 spectra were discarded. A network was then created where edges were filtered to have a cosine score above 0.7 and more than 6 matched peaks. Further edges between two nodes were kept in the network if and only if each of the nodes appeared in each other's respective top 10 most similar nodes. The spectra in the network were then searched against GNPS's spectral libraries. The library spectra were filtered in the same manner as the input data. All matches kept between network spectra and library spectra were required to have a score above 0.7 and at least 6 matched peaks. To visualise the data, they were imported into Cytoscape suite (Version 3.0.2)[84] from this visualisation software, and nodes and edges were displayed (nodes correspond to a specific consensus spectrum; edges represent significant pairwise alignment between nodes). Cosine similarity scores, range from 0 to 1 ( 1 being identical spectra), were computationally combined as consensus spectra if more than six ion fragmentation spectra matched. A minimum cosine score of 0.7 was selected to subdue the clustering of different compound classes under the same molecular family when visualising the data as a network of nodes connected by edges [85]. Rarefaction curves portraying the diversity of MS/MS spectra were computed (with clusters affected equaling the number of clusters of which the file is a constituent) using GNPS [81].

\subsection{Mass Spectrometry Chemical Dereplication}

Mass spectrometry data was processed using a predefined metabolomics workflow described previously [79]. Raw positive ionisation mode data files were sliced using the MassConvert tool from ProteoWizard [86]. The sliced data sets were imported and processed in MZmine 2.10 [87] using settings described previously [79]. The processed data was incorporated into a macro embedded with the molecular formula data sets from Antibase ${ }^{\circledR}$ (February 2013) and Marinlit ${ }^{\circledR}$ (September 2013) which was used for peak identification and dereplication [76]. The data set was further analyzed using SIMCA-P V 13.0 using the unsupervised statistical analysis method, principal component analysis (PCA). Heat maps were generated using the programming software $\mathrm{R}$ (version $\times 642.15 .2$ ) (R Foundation for Statistical Computing, Vienna, Austria) using a script utilising the g-plot package to plot all $\mathrm{m} / \mathrm{z}$ ratios from the sample set. 


\subsection{DNA Extraction, PCR Amplification, $16 \mathrm{~S}$ rRNA Gene Sequencing of Bacterial Isolates}

Pure bacterial isolates were cultured in ISP-2 media (5 mL) [78]. Genomic DNA was extracted from each cell pellet according to established protocols [88]. Polymerase chain reaction (PCR) amplification of the $16 \mathrm{~S}$ rRNA gene was conducted in $50 \mu \mathrm{L}$ volumes and consisted of the following: MyTaq ${ }^{\circledR}$ Red $2 \times$ Master Mix $(25 \mu \mathrm{L})$ (Bioline Reagents Ltd., UK), $0.2 \mu \mathrm{M}$ 27f (5'-AGAGTTTGATCMTGGCTCA-3') and 1492r (5'-TACGGYTACCTTGTTACGACT-3') primers [89], and genomic DNA $\left(1 \mu \mathrm{L}\right.$ of a $10^{-1}$ dilution). Thermocycling parameters consisted of initial denaturation at $95.0^{\circ} \mathrm{C}$ for $5: 00 \mathrm{~min}, 30$ cycles of $94.0^{\circ} \mathrm{C}$ for $0: 10 \mathrm{~min}, 55.0^{\circ} \mathrm{C}$ for $0: 30 \mathrm{~min}$ and $72.0^{\circ} \mathrm{C}$ for 3:00 $\mathrm{min}$ followed by a final extension at $72.0^{\circ} \mathrm{C}$ for 10:00 min. PCR amplification was evaluated by agarose gel electrophoresis $(0.5 \%$ agarose, $1 \times$ TBE buffer strained with ethidium bromide) [90]. 16S rRNA gene amplicons were sequenced by LGC Genomics (Germany) using the primers $27 \mathrm{f}$ and $1492 \mathrm{r}$. Sequences $(\approx 1500$ base pairs) were analysed and edited using the CodonCode Aligner software (Version 5.0.2) package (CodonCode Corporation, MA, USA).

\subsection{Taxonomic Identification and Phylogeny of Bacterial Isolates}

$16 \mathrm{~S}$ rRNA gene sequences for all 85 bacterial isolates were trimmed ( 0.05 error probability) using Geneious (version 8.1.5) [91]. Isolate $16 \mathrm{~S}$ rRNA gene sequences were compared to sequences within the NCBI database using the Megablast Search Tool [92] within Geneious [91], and the results for closest match based on query coverage and sequence identity are shown in Table S1. Sequences were deposited in the NCBI database under the accession numbers KT200430-KT200510. Multiple alignment of all $8516 \mathrm{~S}$ rRNA gene sequences was achieved using a Clustal W [93] alignment with a IUB cost matrix (gap open cost 15, gap extend cost 6.66) using Geneious software (version 8.1.5) [91]. A consensus Neighbour-Joining tree [94] using a Jukes-Cantor [95] genetic distance model was computed using Geneious software (version 8.1.5) [91] with 1000 bootstrap re-samplings and a support threshold of $50 \%$.

\subsection{Bioactivity Testing of Fermentation Extracts Against Three Cell Lines}

Caco-2 cells were purchased from ATCC and cultured in an incubator in $5 \% \mathrm{CO}_{2}$ at $37^{\circ} \mathrm{C}$. Caco-2 cells were seeded at a density of $2 \times 10^{4}$ cells / well in $100 \mu \mathrm{L}$ of the growth medium Minimum Essential Medium alpha (MEM $\alpha$ ) supplemented with 20\% foetal bovine serum (FBS). After 48 h the growth medium was replaced with $80 \mu \mathrm{L}$ of new medium that contained metabolite extracts at different concentrations $(50 \mu \mathrm{g} / \mathrm{mL}, 10 \mu \mathrm{g} / \mathrm{mL}, 5 \mu \mathrm{g} / \mathrm{mL}, 1 \mu \mathrm{g} / \mathrm{mL}$ and $0.5 \mu \mathrm{g} / \mathrm{mL})$. Cells were incubated for 48 hours before adding $20 \mu \mathrm{L}$ of $50 \%$ PrestoBlue ${ }^{\circledR}$ (resazurin based, Life Technologies) solution (diluted with growth media) for viability measurements. This mixture was incubated for $60 \mathrm{~min}$ before reading the fluorescence $(570 / 585 \mathrm{~nm}(\mathrm{ex} / \mathrm{em}))$. The percentage of treated cell viability was calculated and compared to untreated cells. The $\mathrm{IC}_{50}$ was calculated as the concentration of metabolites needed to reduce viability to $50 \%$. Tests were done in triplicate. Additionally, cells were observed and micrographs taken using an EVOS XL Core imaging station (Life Technologies) with phase contrast before treatment, after $24 \mathrm{~h}$ and $48 \mathrm{~h}$.

Normal fibroblasts derived from human foreskin (HS27 cells) and normal epithelial cells derived from human prostate (PNT2 cells) were obtained from ECACC (Sigma-Aldrich, Dorset, UK). HS27 cells were cultured in Dulbecco's Modified Eagle's Medium (DMEM) and PNT2 cells were cultured in RPMI 1640 media; both were supplemented with $10 \%(v / v)$ foetal bovine serum, $2 \mathrm{mM}$ glutamine and $50 \mu \mathrm{g} / \mathrm{mL}$ penicillin/streptomycin solution (all Invitrogen, Paisley, UK) in a humidified incubator at $37^{\circ} \mathrm{C}$ in the presence of $5 \% \mathrm{CO}_{2}$. Cells were routinely passaged at $90 \%-95 \%$ confluence. Subsequently, cells were seeded at a concentration of 7500 (HS27) or 3750 (PNT2) cells/well in clear 96 flat-bottomed plates and allowed to adhere overnight. After that time, metabolite extracts were added at a final concentration of $30 \mu \mathrm{g} / \mathrm{mL}$ and allowed to incubate for 42 hours. Viability was determined using Alamar Blue ${ }^{\circledR}$ (Thermo Fisher, Paisley, UK), according to the manufacturer's instructions and incubated 
for a further $6 \mathrm{~h}$. The resulting fluorescence was measured using a Wallac Victor 21420 multi-label counter (Perkin Elmer, Beaconsfield, UK), in fluorescence mode: excitation 560, emission 590. Vehicle treated control cells (media with 0.3\% DMSO) were considered 100\% viable against which metabolite extract treated cells (at a concentration of $30 \mu \mathrm{g} / \mathrm{mL}$, at least $n=2$ ) were compared. All results were confirmed microscopically.

\section{Conclusions}

This study is, to our knowledge, the first to use molecular networking to address the influence of bacterial isolation location on secondary metabolite production within the marine environment. The results accentuated the importance of bacterial isolation location when bioprospecting for novel bioactive compounds. In this study, it was found that $40 \%$ and $42 \%$ of parent ions were unique to Antarctic or Scotland, respectively (with only $8 \%$ shared between these locations), implying a high degree of biogeographic influence upon secondary metabolite production. Molecular networking combined with PCA metabolomics based dereplication were shown to be valuable tools for microbial ecologists and drug discovery chemists alike, where the matching of identical as well as related molecules allows metabolite patterns to be inferred and compounds to be prioritized for further chemical investigation. Comparative metabolomics aided in the metabolite dereplication of over 3500 parent ions from these understudied marine sources and has provided targets for further purification. Furthermore, due to the success of actinomycete bioactive metabolites for applications in biotechnology and biomedicine, the isolation of 13 Streptomyces strains (including two from Antarctic sediment) and the generation of metabolite extracts with activity against epithelial colon adenocarcinoma cells is highly desirable.

Supplementary Materials: The following are available online at www.mdpi.com/2218-1989/6/1/2/s1, Figure S1: A total of sixty-seven bacteria by Scottish isolation location and media, Figure S2: A total of eighteen bacteria by Antarctica isolation location and media, Figure S3: Rarefaction curve of MS/MS spectra diversity for the molecular network of 3558 parent ions from 38 bacteria strains (Figure 2) where clusters affected is the number of spectra in each data file (strain) and dataset counts is the number of strains added, Figure S4: Molecular network by parent ion $\mathrm{m} / \mathrm{z}$, comprising 3558 nodes, colours indicate parent ion mass ranges from m/z 149 to 2558 as indicated in the LEGEND, Figure S5: Molecular Network comprising 3395 nodes, Figure S6: Heat map of 38 bacterial fermentation extracts based on mass spectrometry data indicating the distinct metabolic profiles amongst the strains. The strains observed as outliers in PCA are labelled with an asterisk *, Figure S7: (a) Principle component analysis scoring plot of 38 bacterial fermentation extracts based on mass spectrometry data indicating outlier strains with novel chemistry; (b) Loadings plot indicating metabolites present in outlying extracts responsible for separation observed in scoring plot, Figure S8: Molecular network using HR-MS/MS data of fermentation extracts from 38 bacteria strains,Table S1: Taxonomic identification of 85 bacterial isolates, derived through the NCBI (National Centre for Biotechnology Information) Megablast Search Tool (BLASTx) database, Table S2: Correlation of parent ions contributing to strains identified as outliers in PCA analysis (Figure S6) to parent ions in the molecular network (Figure 2) as depicted in Figure S7 boxes A-C, Table S3: Bioactivity testing of fermentation extracts from 38 strains and two media blank crude extracts against epithelial colon adenocarcinoma cells (Caco-2) and "normal" human fibroblasts (HS27) and prostate cells (PNT2a).

Acknowledgments: The research leading to these results received funding from the European Union Seventh Framework Program under grant agreement number 311932 (project SeaBioTech). Authors K.P. and K.R.D. would like to thank John Howe for allowing samples from the Scottish Association for Marine Science sediment cores to be taken and Natalie Hicks for sediment collection from St. Andrews. Grainne Abbott (University of Strathclyde) is acknowledged for performing HS27 and PNT2 viability bioassay testing of the crude metabolite extracts.

Author Contributions: Katherine R. Duncan conceived the experiments, Kevin Purves and Katherine R. Duncan organized and conducted sediment sampling, Kevin Purves isolated and sub-cultured pure colonies from isolation plates. Kevin Purves and Debra Brennan conducted PCR gene amplification, taxonomic identification, fermentation and chemical extraction of the isolates. Kevin Purves and Katherine R. Duncan conducted the molecular networking analysis. David H. Green assisted with the phylogenetic tree. Lynsey Macintyre and Ruangelie Edrada-Ebel conducted the HR-MS/MS analysis of crude extract samples and preformed metabolmics via PCA and metabolite dereplication using metabolite databases. Katherine R. Duncan, Lynsey Macintyre and Kevin Purves analysed results. Guðmundur Ó. Hreggviðsson, Eva Kuttner and Margrét E. Ásgeirsdóttir conducted bioactivity testing of crude extracts against Caco-2 cells and Eva Kuttner analysed these results. Louise C. Young conducted bioactivity testing of crude extracts against HS27 and PNT2 cells.

Conflicts of Interest: The author declares no conflicts of interest. 


\section{References}

1. David, A.H. Streptomyces in Nature and Medicine: the Antibiotic Makers; Oxford University Press: Oxford, UK, 2007.

2. Kayser, O.; Kiderlen, A.F.; Croft, S.L. Natural products as antiparasitic drugs. Parasitol. Res. 2003, 90 (Suppl. 2), S55-S62. [CrossRef] [PubMed]

3. Wright, A.D.; Konig, G.M.; Angerhofer, C.K.; Greenidges, P.; Linden, A.; Desqueyroux-Faundez, R. Antimalarial Activity: The Search for Marine-Derived Natural Products with Selective Antimalarial Activity. J. Nat. Prod. 1996, 59, 710-716. [CrossRef] [PubMed]

4. Clark, B.R.; Engene, N.; Teasdale, M.E.; Rowley, D.C.; Matainaho, T.; Valeriote, F.A.; Gerwick, W.H. Natural products chemistry and taxonomy of the marine cyanobacterium Blennothrix cantharidosmum. J. Nat. Prod. 2008, 71, 1530-1537. [CrossRef] [PubMed]

5. Mann, J. Natural products as immunosuppressive agents. Nat. Prod. Rep. 2001, 18, 417-430. [CrossRef] [PubMed]

6. Miyanaga, A.; Janso, J.E.; McDonald, L.; He, M.; Liu, H.; Barbieri, L.; Eustáquio, A.S.; Fielding, E.N.; Carter, G.T.; Jensen, P.R.; et al. Discovery and assembly-line biosynthesis of the lymphostin pyrroloquinoline alkaloid family of mTOR inhibitors in Salinispora bacteria. J. Am. Chem. Soc. 2011, 133, 13311-13313. [CrossRef] [PubMed]

7. Simmons, T.L.; Andrianasolo, E.; McPhail, K.; Flatt, P.; Gerwick, W.H. Marine natural products as anticancer drugs. Mol. Cancer Ther. 2005, 4, 333-342. [PubMed]

8. Eustáquio, A.S.; McGlinchey, R.P.; Liu, Y.; Hazzard, C.; Beer, L.L.; Florova, G.; Alhamadsheh, M.M.; Lechner, A.; Kale, A.J.; Kobayashi, Y.; et al. Biosynthesis of the salinosporamide A polyketide synthase substrate chloroethylmalonyl-coenzyme A from S-adenosyl-L-methionine. Proc. Natl. Acad. Sci. USA. 2009, $106,12295-12300$.

9. Wyche, T.P.; Hou, Y.; Braun, D.; Cohen, H.C.; Xiong, M.P.; Bugni, T.S. First natural analogs of the cytotoxic thiodepsipeptide thiocoraline A from a marine Verrucosispora sp. J. Org. Chem. 2011, 76, 6542-6547. [CrossRef] [PubMed]

10. Kohanski, M.A.; Dwyer, D.J.; Collins, J.J. How antibiotics kill bacteria: From targets to networks. Nat. Rev. Microbiol. 2010, 8, 423-435. [CrossRef] [PubMed]

11. Lewis, K. Platforms for antibiotic discovery. Nat. Rev. Drug Discov. 2013, 12, 371-387. [CrossRef] [PubMed]

12. Chait, R.; Vetsigian, K.; Kishony, R. What counters antibiotic resistance in nature? Nat. Chem. Biol. 2012, 8, 2-5. [CrossRef] [PubMed]

13. Torella, J.P.; Chait, R.; Kishony, R. Optimal drug synergy in antimicrobial treatments. PLoS Comput. Biol. 2010. [CrossRef]

14. Sogin, M.L.; Morrison, H.G.; Huber, J.A.; Mark Welch, D.; Huse, S.M.; Neal, P.R.; Arrieta, J.M.; Herndl, G.J. Microbial diversity in the deep sea and the underexplored "rare biosphere". Proc. Natl. Acad. Sci. USA. 2006, 103, 12115-12120. [CrossRef] [PubMed]

15. Chu, H.; Fierer, N.; Lauber, C.L.; Caporaso, J.G.; Knight, R.; Grogan, P. Soil bacterial diversity in the Arctic is not fundamentally different from that found in other biomes. Environ. Microbiol. 2010, 12, 2998-3006. [CrossRef] [PubMed]

16. Ganzert, L.; Bajerski, F.; Wagner, D. Bacterial community composition and diversity of five different permafrost-affected soils of Northeast Greenland. FEMS Microbiol. Ecol. 2014, 89, 426-441. [CrossRef] [PubMed]

17. Steven, B.; Pollard, W.H.; Greer, C.W.; Whyte, L.G. Microbial diversity and activity through a permafrost/ground ice core profile from the Canadian high Arctic. Environ. Microbiol. 2008, 10, 3388-3403. [CrossRef] [PubMed]

18. Sunagawa, S.; Woodley, C.M.; Medina, M. Threatened corals provide underexplored microbial habitats. PLoS ONE 2010. [CrossRef] [PubMed]

19. Hentschel, U.; Piel, J.; Degnan, S.M.; Taylor, M.W. Genomic insights into the marine sponge microbiome. Nat. Rev. Microbiol. 2012, 10, 641-654. [CrossRef] [PubMed]

20. Yang, S.; Sun, W.; Tang, C.; Jin, L.; Zhang, F.; Li, Z. Phylogenetic diversity of actinobacteria associated with soft coral Alcyonium gracllimum and stony coral Tubastraea coccinea in the East China Sea. Microb. Ecol. 2013, 66, 189-199. [CrossRef] [PubMed] 
21. Hochmuth, T.; Piel, J. Polyketide synthases of bacterial symbionts in sponges-Evolution-based applications in natural products research. Phytochemistry 2009, 70, 1841-1849. [CrossRef] [PubMed]

22. Montalvo, N.F.; Mohamed, N.M.; Enticknap, J.J.; Hill, R.T. Novel actinobacteria from marine sponges. Antonie Van Leeuwenhoek 2005, 87, 29-36. [CrossRef] [PubMed]

23. Duncan, K.R.; Haltli, B.; Gill, K.A.; Correa, H.; Berrué, F.; Kerr, R.G. Exploring the diversity and metabolic potential of actinomycetes from temperate marine sediments from Newfoundland, Canada. J. Ind. Microbiol. Biotechnol. 2015, 42, 57-72. [CrossRef] [PubMed]

24. Bredholt, H.; Fjaervik, E.; Johnsen, G.; Zotchev, S.B. Actinomycetes from sediments in the Trondheim fjord, Norway: Diversity and biological activity. Mar. Drugs 2008, 6, 12-24. [CrossRef] [PubMed]

25. Riedlinger, J.; Reicke, A.; Zähner, H.; Krismer, B.; Bull, A.T.; Maldonado, L.A.; Ward, A.C.; Goodfellow, M.; Bister, B.; Bischoff, D.; et al. Abyssomicins, inhibitors of the para-aminobenzoic acid pathway produced by the marine Verrucosispora strain AB-18-032. J. Antibiot. 2004, 57, 271-279. [CrossRef] [PubMed]

26. Williams, P.G.; Buchanan, G.O.; Feling, R.H.; Kauffman, C.A.; Jensen, P.R.; Fenical, W. New cytotoxic salinosporamides from the marine Actinomycete Salinispora tropica. J. Org. Chem. 2005, 70, 6196-6203. [CrossRef] [PubMed]

27. Bérdy, J. Bioactive microbial metabolites. J. Antibiot. 2005, 58, 1-26. [CrossRef] [PubMed]

28. Nithya, C.; Devi, M.G.; Karutha Pandian, S. A novel compound from the marine bacterium Bacillus pumilus S6-15 inhibits biofilm formation in gram-positive and gram-negative species. Biofouling 2011, 27, 519-528. [CrossRef] [PubMed]

29. Yang, S.-C.; Lin, C.-F.; Chang, W.-Y.; Kuo, J.; Huang, Y.-T.; Chung, P.-J.; Hwang, T.-L. Bioactive secondary metabolites of a marine Bacillus sp. inhibit superoxide generation and elastase release in human neutrophils by blocking formyl peptide receptor 1. Molecules 2013, 18, 6455-6468. [CrossRef] [PubMed]

30. Mondol, M.A.M.; Shin, H.J.; Islam, M.T. Diversity of secondary metabolites from marine Bacillus species: Chemistry and biological activity. Mar. Drugs 2013, 11, 2846-2872. [CrossRef] [PubMed]

31. Blunt, J.W.; Copp, B.R.; Hu, W.-P.; Munro, M.H.G.; Northcote, P.T.; Prinsep, M.R. Marine natural products. Nat. Prod. Rep. 2007, 24, 31-86. [CrossRef] [PubMed]

32. Pathom-aree, W.; Stach, J.E.M.; Ward, A.C.; Horikoshi, K.; Bull, A.T.; Goodfellow, M. Diversity of actinomycetes isolated from Challenger Deep sediment $(10,898 \mathrm{~m})$ from the Mariana Trench. Extremophiles 2006, 10, 181-189. [CrossRef] [PubMed]

33. Bazire, A.; Diab, F.; Jebbar, M.; Haras, D. Influence of high salinity on biofilm formation and benzoate assimilation by Pseudomonas aeruginosa. J. Ind. Microbiol. Biotechnol. 2007, 34, 5-8. [CrossRef] [PubMed]

34. Ballav, S.; Kerkar, S.; Thomas, S.; Augustine, N. Halophilic and halotolerant actinomycetes from a marine saltern of Goa, India producing anti-bacterial metabolites. J. Biosci. Bioeng. 2015, 119, 323-330. [CrossRef] [PubMed]

35. Starič, N.; Danevčič, T.; Stopar, D. Vibrio sp. DSM 14379 pigment production-A competitive advantage in the environment? Microb. Ecol. 2010, 60, 592-598.

36. McDougald, D.; Rice, S.A.; Barraud, N.; Steinberg, P.D.; Kjelleberg, S. Should we stay or should we go: Mechanisms and ecological consequences for biofilm dispersal. Nat. Rev. Microbiol. 2012, 10, 39-50. [CrossRef] [PubMed]

37. Penn, K.; Jenkins, C.; Nett, M.; Udwary, D.W.; Gontang, E.A.; McGlinchey, R.P.; Foster, B.; Lapidus, A.; Podell, S.; Allen, E.E.; et al. Genomic islands link secondary metabolism to functional adaptation in marine Actinobacteria. ISME J. 2009, 3, 1193-1203. [CrossRef] [PubMed]

38. Ziemert, N.; Lechner, A.; Wietz, M.; Millán-Aguiñaga, N.; Chavarria, K.; Jensen, P.R. Diversity and Evolution of Secondary Metabolism in the Marine Actinomycete Genus Salinispora. Proc. Natl. Acad. Sci. USA. 2014, 111, E1130-E1139. [CrossRef] [PubMed]

39. Bull, A.T. Clean technology: Industry and environment, a viable partnership? Biologist 2000, 47, 61-64. [PubMed]

40. Andrianasolo, E.H.; Haramaty, L.; Rosario-Passapera, R.; Vetriani, C.; Falkowski, P.; White, E.; Lutz, R. Ammonificins $\mathrm{C}$ and $\mathrm{D}$, hydroxyethylamine chromene derivatives from a cultured marine hydrothermal vent bacterium, Thermovibrio ammonificans. Mar. Drugs 2012, 10, 2300-2311. [CrossRef] [PubMed]

41. Watrous, J.; Roach, P.; Alexandrov, T.; Heath, B.S.; Yang, J.Y.; Kersten, R.D.; van der Voort, M.; Pogliano, K.; Gross, H.; Raaijmakers, J.M.; et al. Mass spectral molecular networking of living microbial colonies. Proc. Natl. Acad. Sci. USA. 2012, 109, E1743-E1752. [CrossRef] [PubMed] 
42. Frank, A.M.; Bandeira, N.; Shen, Z.; Tanner, S.; Briggs, S.P.; Smith, R.D.; Pevzner, P.A. Clustering millions of tandem mass spectra. J. Proteome Res. 2008, 7, 113-122. [CrossRef] [PubMed]

43. Nguyen, D.D.; Wu, C.-H.; Moree, W.J.; Lamsa, A.; Medema, M.H.; Zhao, X.; Gavilan, R.G.; Aparicio, M.; Atencio, L.; Jackson, C.; et al. MS/MS networking guided analysis of molecule and gene cluster families. Proc. Natl. Acad. Sci. USA. 2013, 110, E2611-E2620. [CrossRef] [PubMed]

44. Yang, J.Y.; Sanchez, L.M.; Rath, C.M.; Liu, X.; Boudreau, P.D.; Bruns, N.; Glukhov, E.; Wodtke, A.; de Felicio, R.; Fenner, A.; et al. Molecular Networking as a Dereplication Strategy. J. Nat. Prod. 2013, 76, 1686-1699. [CrossRef] [PubMed]

45. Duncan, K.R.; Crüsemann, M.; Lechner, A.; Sarkar, A.; Li, J.; Ziemert, N.; Wang, M.; Bandeira, N.; Moore, B.S.; Dorrestein, P.C.; et al. Molecular Networking and Pattern-Based Genome Mining Improves Discovery of Biosynthetic Gene Clusters and their Products from Salinispora Species. Chem. Biol. 2015, 22, 460-471. [CrossRef] [PubMed]

46. Kersten, R.D.; Ziemert, N.; Gonzalez, D.J.; Duggan, B.M.; Nizet, V.; Dorrestein, P.C.; Moore, B.S. Glycogenomics as a mass spectrometry-guided genome-mining method for microbial glycosylated molecules. Proc. Natl. Acad. Sci. USA. 2013, 110, E4407-E4416. [CrossRef] [PubMed]

47. Kersten, R.D.; Yang, Y.-L.; Xu, Y.; Cimermancic, P.; Nam, S.-J.; Fenical, W.; Fischbach, M.A.; Moore, B.S.; Dorrestein, P.C. A mass spectrometry-guided genome mining approach for natural product peptidogenomics. Nat. Chem. Biol. 2011, 7, 794-802. [CrossRef] [PubMed]

48. Briand, E.; Bormans, M.; Gugger, M.; Dorrestein, P.C.; Gerwick, W.H. Changes in secondary metabolic profiles of Microcystis aeruginosa strains in response to intraspecific interactions. Environ. Microbiol. 2015. [CrossRef] [PubMed]

49. Winnikoff, J.R.; Glukhov, E.; Watrous, J.; Dorrestein, P.C.; Gerwick, W.H. Quantitative molecular networking to profile marine cyanobacterial metabolomes. J. Antibiot. 2014, 67, 105-112. [CrossRef] [PubMed]

50. Fang, J.; Dorrestein, P.C. Emerging mass spectrometry techniques for the direct analysis of microbial colonies. Curr. Opin. Microbiol. 2014, 19, 120-129. [CrossRef] [PubMed]

51. Klitgaard, A.; Nielsen, J.B.; Frandsen, R.J.N.; Andersen, M.R.; Nielsen, K.F. Combining Stable Isotope Labeling and Molecular Networking for Biosynthetic Pathway Characterization. Anal. Chem. 2015, 87, 6520-6526. [CrossRef] [PubMed]

52. Maldonado, L.A.; Stach, J.E.M.; Pathom-Aree, W.; Ward, A.C.; Bull, A.T.; Goodfellow, M. Diversity of cultivable actinobacteria in geographically widespread marine sediments. Antonie Van Leeuwenhoek 2005, 87, 11-18. [CrossRef] [PubMed]

53. Duncan, K.; Haltli, B.; Gill, K.A.; Kerr, R.G. Bioprospecting from marine sediments of New Brunswick, Canada: Exploring the relationship between total bacterial diversity and actinobacteria diversity. Mar. Drugs 2014, 12, 899-925. [CrossRef] [PubMed]

54. Murray, A.E.; Grzymski, J.J. Diversity and genomics of Antarctic marine micro-organisms. Philos. Trans. R. Soc. Lond. B Biol. Sci. 2007, 362, 2259-2271. [CrossRef] [PubMed]

55. Nicholson, W.L.; Munakata, N.; Horneck, G.; Melosh, H.J.; Setlow, P. Resistance of Bacillus endospores to extreme terrestrial and extraterrestrial environments. Microbiol. Mol. Biol. Rev. 2000, 64, 548-572. [CrossRef] [PubMed]

56. Sneath, P. Longevity of microorganisms. Nature 1962, 195, 643-646. [CrossRef] [PubMed]

57. Haselwandter, K.; Ebner, M.R. Microorganisms surviving for 5300 years. FEMS Microbiol. Lett. 1994, 116, 189-193. [CrossRef] [PubMed]

58. Jensen, P.R.; Gontang, E.; Mafnas, C.; Mincer, T.J.; Fenical, W. Culturable marine actinomycete diversity from tropical Pacific Ocean sediments. Environ. Microbiol. 2005, 7, 1039-1048. [CrossRef] [PubMed]

59. Zhang, H.; Zhang, W.; Jin, Y.; Meifang, J.; Yu, X. A comparative study on the phylogenetic diversity of culturable actinobacteria isolated from five marine sponge species. Antonie Van Leeuwenhoek 2008, 93, 241-248. [CrossRef] [PubMed]

60. Maldonado, L.A.; Fragoso-Yáñez, D.; Pérez-García, A.; Rosellón-Druker, J.; Quintana, E.T. Actinobacterial diversity from marine sediments collected in Mexico. Antonie Van Leeuwenhoek 2009, 95, 111-120. [CrossRef] [PubMed]

61. Mincer, T.J.; Jensen, P.R.; Kauffman, C.A.; Fenical, W. Widespread and Persistent Populations of a Major New Marine Actinomycete Taxon in Ocean Sediments. Appl. Environ. Microbiol. 2002, 68, 5005-5011. [CrossRef] [PubMed] 
62. Weyland, H. Actinomycetes of the bottom sediments of various seas. In Proceedings of the Colloque International de Bacteriologie Marine, Brest, France, 1-5 October 1986; pp. 73-79.

63. Sass, A.M.; McKew, B.A; Sass, H.; Fichtel, J.; Timmis, K.N.; McGenity, T.J. Diversity of Bacillus-like organisms isolated from deep-sea hypersaline anoxic sediments. Saline Syst. 2008. [CrossRef] [PubMed]

64. Da Silva, M.A.C.; Cavalett, A.; Spinner, A.; Rosa, D.C.; Jasper, R.B.; Quecine, M.C.; Bonatelli, M.L.; Pizzirani-Kleiner, A.; Corção, G.; Lima, A.O.D.S. Phylogenetic identification of marine bacteria isolated from deep-sea sediments of the eastern South Atlantic Ocean. Springerplus 2013, 2, 127. [CrossRef] [PubMed]

65. Palomo, S.; González, I.; de La Cruz, M.; Martín, J.; Tormo, J.R.; Anderson, M.; Hill, R.T.; Vicente, F.; Reyes, F.; Genilloud, O. Sponge-derived Kocuria and Micrococcus spp. as sources of the new thiazolyl peptide antibiotic kocurin. Mar. Drugs 2013, 11, 1071-1086. [CrossRef] [PubMed]

66. Jensen, P.R.; Williams, P.G.; Oh, D.-C.; Zeigler, L.; Fenical, W. Species-specific secondary metabolite production in marine actinomycetes of the genus Salinispora. Appl. Environ. Microbiol. 2007, 73, 1146-1152. [CrossRef] [PubMed]

67. Jensen, P.R.; Mafnas, C. Biogeography of the marine actinomycete Salinispora. Environ. Microbiol. 2006, 8, 1881-1888. [CrossRef] [PubMed]

68. Charlop-Powers, Z.; Owen, J.G.; Reddy, B.V.B.; Ternei, M.A; Brady, S.F. Chemical-biogeographic survey of secondary metabolism in soil. Proc. Natl. Acad. Sci. USA. 2014, 111, 3757-3762. [CrossRef] [PubMed]

69. Dunshee, B.R.; Leben, C.; Keitt, G.W.; Strong, F.M. The Isolation and Properties of Antimycin A. J. Am. Chem. Soc. 1949, 71, 2436-2437. [CrossRef]

70. Viegelmann, C.; Margassery, L.M.; Kennedy, J.; Zhang, T.; O’Brien, C.; O'Gara, F.; Morrissey, J.P.; Dobson, A.D.W.; Edrada-Ebel, R. Metabolomic profiling and genomic study of a marine sponge-associated Streptomyces sp. Mar. Drugs 2014, 12, 3323-3351. [CrossRef] [PubMed]

71. Liaw, C.-C.; Chen, P.-C.; Shih, C.-J.; Tseng, S.-P.; Lai, Y.-M.; Hsu, C.-H.; Dorrestein, P.C.; Yang, Y.-L. Vitroprocines, new antibiotics against Acinetobacter baumannii, discovered from marine Vibrio sp. QWI-06 using mass-spectrometry-based metabolomics approach. Sci. Rep. 2015. [CrossRef] [PubMed]

72. Vijayabharathi, R.; Bruheim, P.; Andreassen, T.; Raja, D.S.; Devi, P.B.; Sathyabama, S.; Priyadarisini, V.B. Assessment of resistomycin, as an anticancer compound isolated and characterized from Streptomyces aurantiacus AAA5. J. Microbiol. 2011, 49, 920-926. [CrossRef] [PubMed]

73. Schorn, M.; Zettler, J.; Noel, J.P.; Dorrestein, P.C.; Moore, B.S.; Kaysser, L. Genetic basis for the biosynthesis of the pharmaceutically important class of epoxyketone proteasome inhibitors. ACS Chem. Biol. 2014, 9, 301-309. [CrossRef] [PubMed]

74. Ohba, M.; Mizuki, E.; Uemori, A. Parasporin, a new anticancer protein group from Bacillus thuringiensis. Anticancer Res. 2009, 29, 427-433. [PubMed]

75. Ma, E.L.; Choi, Y.J.; Choi, J.; Pothoulakis, C.; Rhee, S.H.; Im, E. The anticancer effect of probiotic Bacillus polyfermenticus on human colon cancer cells is mediated through ErbB2 and ErbB3 inhibition. Int. J. Cancer 2010, 127, 780-790. [PubMed]

76. Howe, J.A.; Shimmield, T.M.; Diaz, R. Deep-water sedimentary environments of the northwestern Weddell Sea and South Sandwich Islands, Antarctica. Deep Sea Res. 2004, 51, 1489-1514. [CrossRef]

77. Sea, N.W.; Howe, J.A.; Wilson, C.R.; Shimmield, T.M.; Diaz, R.J.; Carpenter, L.W. Recent deep-water sedimentation, trace metal and radioisotope geochemistry across the Southern Ocean and Northern Weddell Sea, Antarctica. Deep Sea Res. 2007, 54, 1652-1681.

78. Shiring, E.B.; Gottlieb, D. Methods for the Characterization of Streptomyces species. Int. J. Syst. Evol. Microbiol. 1966, 16, 313-340.

79. Macintyre, L.; Zhang, T.; Viegelmann, C.; Martinez, I.J.; Cheng, C.; Dowdells, C.; Abdelmohsen, U.R.; Gernert, C.; Hentschel, U.; Edrada-Ebel, R. Metabolomic tools for secondary metabolite discovery from marine microbial symbionts. Mar. Drugs 2014, 12, 3416-3448. [CrossRef] [PubMed]

80. Deutsch, E.W.; Mendoza, L.; Shteynberg, D.; Farrah, T.; Lam, H.; Sun, Z.; Nilsson, E.; Pratt, B.; Prazen, B.; Eng, J.K.; et al. A Guided Tour of the Trans-Proteomic Pipeline. Proteomics 2011, 10, 1150-1159. [CrossRef] [PubMed]

81. GNPS. The Future of Natural Products Research and Mass Spectrometry. Available online: http://gnps.ucsd.edu/ProteoSAFe/static/gnps-splash.jsp (accessed on 7 January 2016).

82. Guthals, A.; Watrous, J.D.; Dorrestein, P.C.; Bandeira, N. The spectral networks paradigm in high throughput mass spectrometry. Mol. Biosyst. 2012, 8, 2535-2544. [CrossRef] [PubMed] 
83. Keller, A.; Eng, J.; Zhang, N.; Li, X.; Aebersold, R. A uniform proteomics MS/MS analysis platform utilizing open XML file formats. Mol. Syst. Biol. 2005. [CrossRef] [PubMed]

84. Smoot, M.E.; Ono, K.; Ruscheinski, J.; Wang, P.-L.; Ideker, T. Cytoscape 2.8: New features for data integration and network visualization. Bioinformatics 2011, 27, 431-432. [CrossRef] [PubMed]

85. Cline, M.S.; Smoot, M.; Cerami, E.; Kuchinsky, A.; Landys, N.; Workman, C.; Christmas, R.; Avila-Campilo, I.; Creech, M.; Gross, B.; et al. Integration of biological networks and gene expression data using Cytoscape. Nat. Protoc. 2007, 2, 2366-2382. [CrossRef] [PubMed]

86. Chambers, M.C.; Maclean, B.; Burke, R.; Amodei, D.; Ruderman, D.L.; Neumann, S.; Gatto, L.; Fischer, B.; Pratt, B.; Egertson, J.; et al. A cross-platform toolkit for mass spectrometry and proteomics. Nat. Biotechnol. 2012, 30, 918-920. [CrossRef] [PubMed]

87. Pluskal, T.; Castillo, S.; Villar-Briones, A.; Oresic, M. MZmine 2: Modular framework for processing, visualizing, and analyzing mass spectrometry-based molecular profile data. BMC Bioinform. 2010. [CrossRef] [PubMed]

88. Hopwood, D.A.; Bibb, M.J.; Chater, K.F.; Kieser, T.; Bruton, C.J.; Kieser, H.M.; Lydiate, D.J.; Smith, C.P.; Ward, J.M.; Schrempf, H. Genetic Manipulation of Streptomyces: A laboratory manual. Biochem. Educ. 1986. [CrossRef]

89. Weisburg, W.G.; Barns, S.M.; Pelletie, D.A; Lane, D.J. 16S ribosomal DNA amplification for phylogenetic study. J. Bacteriol. 1991, 173, 697-703. [PubMed]

90. Sambrook, J.; Russel, D.W. Molecular Cloning: A Laboratory Manual; Cold pring Harbor Laboratory Press: New York, NY, USA, 2001.

91. Kearse, M.; Moir, R.; Wilson, A.; Stones-Havas, S.; Cheung, M.; Sturrock, S.; Buxton, S.; Cooper, A.; Markowitz, S.; Duran, C.; et al. Geneious Basic: An integrated and extendable desktop software platform for the organization and analysis of sequence data. Bioinformatics 2012, 28, 1647-1649. [CrossRef] [PubMed]

92. Altschul, S.F.; Gish, W.; Miller, W.; Myers, E.W.; Lipman, D.J. Basic Local Alignment Search Tool. J. Mol. Biol. 1990, 215, 403-410. [CrossRef]

93. Thompson, J.D.; Higgins, D.G.; Gibson, T.J. CLUSTAL W: Improving the sensitivity of progressive multiple sequence alignment through sequence weighting, position-specific gap penalties and weight matrix choice. Nucleic Acids Res. 1994, 22, 4673-4680. [CrossRef] [PubMed]

94. Saitou, N.; Nei, M. The neighbor-joining method: A new method for reconstructing phylogenetic trees. Mol. Biol. Evol. 1987, 4, 406-425. [PubMed]

95. Jukes, T.H.; Cantor, C.R. Evolution of Protein Models; Academic Press: New York, NY, USA, 1969.

(C) 2016 by the authors; licensee MDPI, Basel, Switzerland. This article is an open access article distributed under the terms and conditions of the Creative Commons by Attribution (CC-BY) license (http:/ / creativecommons.org/licenses/by/4.0/). 